\title{
Growth of the Azuki Bean weevil (Callosobruchus chinensis L.) and the Mexican Bean Weevil (Zabrotes subfasciatus Вон.) on Beans of Grafted Phaseolus Plants
}

\author{
By Kenji UMEYA \\ Yokohama Plant Protection Station, Yokohama \\ and \\ Eiichi IMAI $^{1}$ \\ Fukushima Horticultural Experiment Station, Taira
}

\section{INTRODUCTION}

The azuki bean weevil (Callosobruchus chinensis L.) is able to complete its larval growth when fed on the azuki bean (Phaseolus radiatus L.) and certain other species of beans. Although the kidney bean (Phaseolus vulgaris L.) is congeneric with the azuki bean, it is completely free from infestation of this bruchid. If the adult female lays her eggs on the kidney beans, the hatched larvae die just after they burrow in the kidney beans. IsHII (1952) studied this conspicuous phenomenon from the view point of nutritional physiology and came to the conclusion that some chemical factors in the kidney bean prevent the larval development. Apparently, several components are involved, but they are as yet not identified.

On the contrary, the Mexican bean weevil (Zabrotes subfasciatus Bон.) is able to develope on the kidney bean as well as on the azuki bean. For this weevil, the former bean seems to be a more favourable food than the latter, inasmuch as the larva takes about 9 days less to mature at $25^{\circ} \mathrm{C}$ when fed on the kidney bean. This also is presumably due to the difference in chemical composition between the two species of beans.

To determine the plant parts responsible for the synthesis of the critical substances, it is a useful approach to introduce a grafting experiment between the azuki and kidney bean plants. In the preceding paper, less responsibility of the root of the kidney bean plant for the production of the substances preventing the growth of the azuki bean weevil, were reported based on the rearing experiments of the weevil larvae on beans harvested from azuki scions grafted on kidney bean stocks (UMEYA and IMAI, 1963). In the present work, the leaves of the azuki scions or the kidney bean stocks were removed for estimating the significance of leaves on the chemical and biological characteristics of the beans. Two species of the bean weevils were reared on beans produced by such different grafted plants.

Studies along similar lines have been carried out by several workers. MüLLER and HENNIG (1960) elucidated by grafting between varieties of the broad bean that the varietal difference in the resistance to aphid infestation is not dependent on substances formed in the root. BuHR (1954) grafted tobacco on potato plants and showed that nicotine is responsible for preventing the Colorado potato beetle from feeding on to

1 Present address : Fukushima Agricultural Experiment Station, Hama Branch, Sōma (Received for publication, June 25, 1965) 
bacco leaves.

\section{MATERIALS AND METHODS}

Plant An early crop variety, Takara azuki, of the azuki bean was used as a scion, and a dwarf variety, Top crop, of the kidney bean as a stock plant. Both species of beans were germinated at $30^{\circ} \mathrm{C}$ in an incubator. The germinated seeds of the kidney bean were sown in porous pots of 15 $\mathrm{cm}$ diameter. A single plant was grown in each pot and 300 such pots were prepared. The azuki seeds were sown in a group of 400 in an wooden tray $(60 \times 120 \times 10 \mathrm{~cm})$.

Operation of grafting When the second leaf of the kidney bean seedling expanded, the upper part of the stalk was cut off at the level $2 \mathrm{~cm}$ from the top of the second segment. Azuki seedlings were cut at the ground level when they expanded their first leaves. These scions, the epidermis of which was partly removed, were placed on the stock plants, and fixed tightly with paper bands (Fig. 1).

Culturing of grafted plants After grafting, the plants were kept in darkness

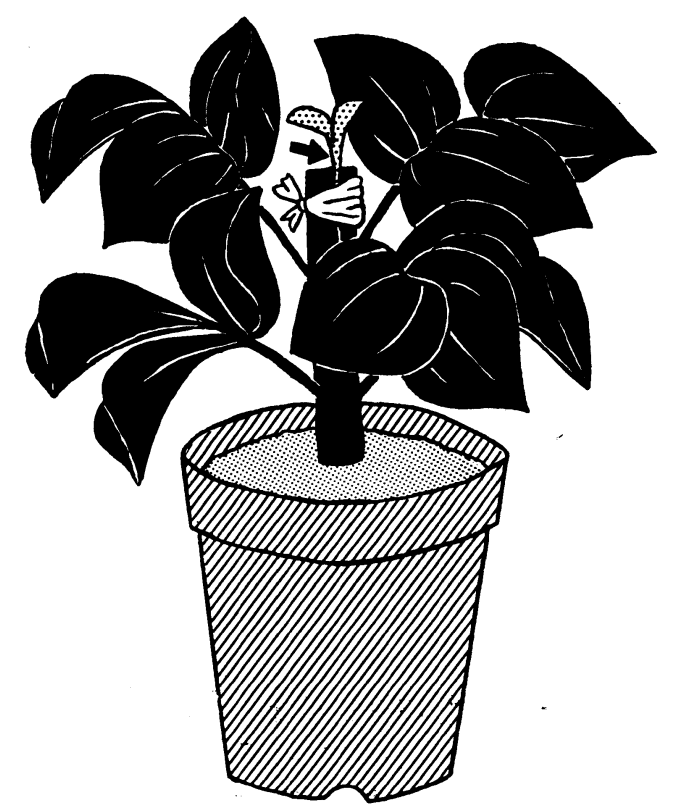

Fig. 1. Grafted bean plant.

Stock : Kidney bean plant.

Scion: Azuki bean plant. under moist conditions. The temperature was not controlled, fluctuating between $15^{\circ}$ and $30^{\circ} \mathrm{C}$. When the scions were found to be settled on the stocks, the light intensity and ventilation were gradually increased. Ten days later the plants were exposed to intense light in a greenhouse, kept there for 3 days and then transplanted to an experimental field $1 \mathrm{~m}$ apart from one another. Immediately after transplantation, the leaves were removed from the scions or stocks of certain plants according to the experimental design referred to below. Just prior to flowering, every plant was covered with fine cheese cloth in order to avoid outcrossing. When the temperature decreased in autumn, the plants were covered with vinyl sheets to keep warmth. The beans were harvested as they became ripen on the azuki scions. The time schedule of all these procedures is summarized in Table 1.

Table 1. Schedule for growing test beans

Date

Procedure

July 25 Sowing of kidney beans for stocks

August 3 Sowing of azuki beans for scions 15-17 Grafting

21 Reed-blind removed, aeration started

30 Transferred to greenhouse

Sept. 2 Planting out and arrangement of experimental plots

Nov. $20 \sim$ Beans harvest

Besides the grafted plants, the untreated azuki and kidney bean plants, 20 individuals each, were cultured on the same field in order to obtain the control beans.

Design of removing leaves Out of 100 grafted plants, 74 survived. From these 60 relatively vigorous plants were selected, which allotted to three groups, each comprising of 20 plants. The three groups were subjected to different treatments throughout the growing period as follows (Fig. 2).

A-leaf treatment - - A All leaves developed from the stock (kidney bean plant) were removed, so that the azuki leaves and the kidney bean roots would be responsible for the seed production. 


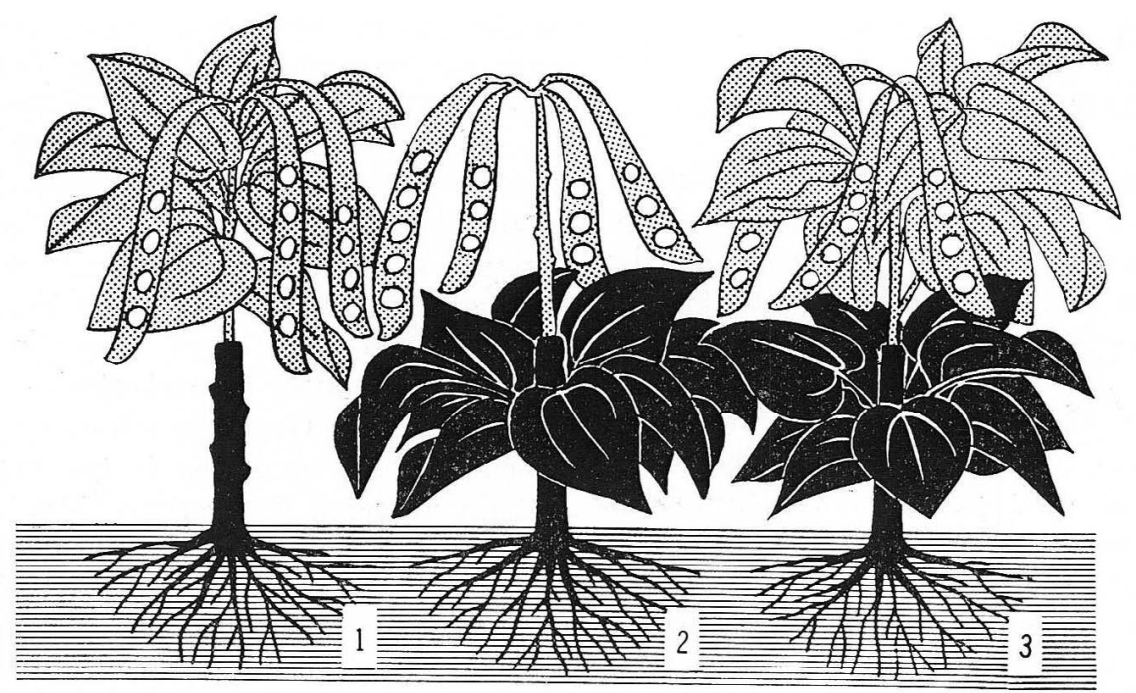

Fig. 2. Illustration of grafting plants 1 : A-leaf plant. 2 : K-leaf plant. 3 : AK-leaf plant.

K-leaf treatment--- All leaves developed from the scion (azuki) were removed, so that the leaves and roots of only the kidney bean stocks would influence the production of seeds.

AK-leaf treatment--- The leaves of both scion and stock were left intact; the leaves of the two species of bean plants and the root of kidney plants might participate in growing the seeds.

In all cases, the flower buds of the stocks were removed. This was necessary to prevent early blasting; if the stock bore its own pods, it would die before the azuki bean on seion became ripen, because the kidney beans tended to ripe earlier than the azuki beans. In the AK-leaf plants, leaves were collected just before defoliation, and the leaf areas of the scion and stock were measured. From these measurements the scion-stock leaf area ratio was calculated.

Rearing of insects The strain of the azuki bean weevil used in this work was derived from the laboratory stock which has been maintained for a number of generations in the Yokohama Plant Protection Station. The strain of the Mexican bean weevil was established from specimens found through quarantine inspection in imported Burmese agricultural products (Fig. 3).

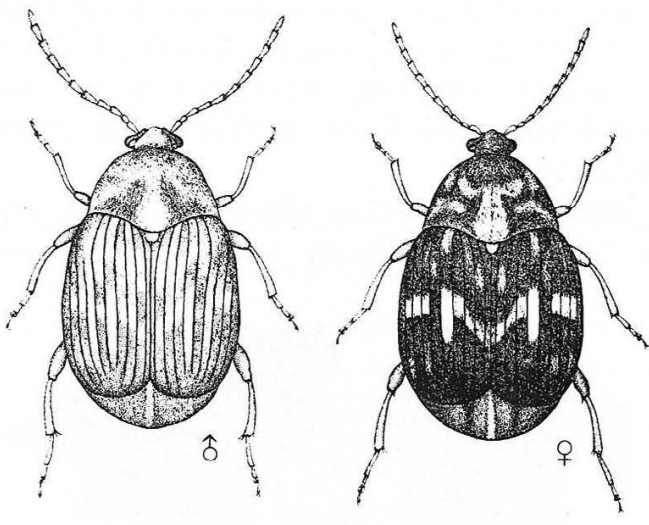

Fig. 3. Zabrotes subfasciatus Вон.

Throughout the experiments, beans were kept under separated groups, each of them corresponded to the individual plant. All the beans used were placed in a large container under separated groups, and oviposited by a group of adult azuki bean weevils, 200 pairs, within 48 hours after emergence. Number of beans used was given in Table 4. After oviposition period of 12 hours, the weevils were removed, and groups of beans were transferred from the oviposition container to petri dishes, a group to a dish. The number of eggs hatched and of adults emerged were recorded daily to determine the duration of pre-imaginal development and mortality 
Table 2. The number and weight of the beans grown on grafted and normal plants

\begin{tabular}{|c|c|c|c|}
\hline \multicolumn{2}{|c|}{ Treatment } & $\begin{array}{l}\text { No. of } \\
\text { plants }\end{array}$ & $\begin{array}{c}\text { No. of } \\
\text { matured } \\
\text { plants }\end{array}$ \\
\hline Grafted & $\begin{array}{l}\text { A-leaf } \\
\text { K-leaf } \\
\text { AK-leaf }\end{array}$ & $\begin{array}{l}20 \\
20 \\
20\end{array}$ & $\begin{array}{l}15 \\
15 \\
16\end{array}$ \\
\hline Control & $\begin{array}{l}\text { Azuki bean } \\
\text { Kidney bean }\end{array}$ & $\begin{array}{l}20 \\
20\end{array}$ & $\begin{array}{l}19 \\
19\end{array}$ \\
\hline
\end{tabular}

during the development.

Similar procedures were adopted for oviposition by the Mexican bean weevil. But due to an erroneous introduction of a large number of adult weevils, 300 pairs, into the oviposition container, it resulted in heavy population density of eggs. Number of beans used was given in Table 5 .

Rearing of larvae of both species was carried out in a 'Biotron' in which the temperature was regulated at $25^{\circ} \mathrm{C}$ and relative humidity was 70 per cent.

\section{RESULTS}

Bean production on grafted plants Average number and weight of the beans produced by grafted plants of respective groups are given in Table 2 . The number of beans on each plant varied considerably among individuals, but on the average the yield on grafted plants smaller than the untreated (control) azuki plants. This was probably due to the poor growth of the scion. On the contrary, the average weight of beans on grafted plants was never inferior

Table 3. The ratio of leaf areas between the scion and stock in the AK-leaf plant

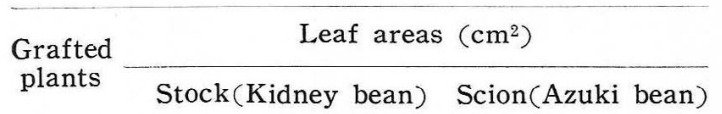

$\begin{array}{rll}\text { No. } 1 & 4944(96.1 \%) & 202(3.9 \%) \\ 2 & 5093(96.6) & 179(3.4) \\ 3 & 5483(94.9) & 295(5.1) \\ 4 & 4388(94.8) & 241(5.2) \\ 5 & 5436(96.0) & 227(4.0) \\ 6 & 4792(93.8) & 317(6.2) \\ 7 & 3694(91.5) & 347(8.5) \\ 8 & 5609(94.5) & 327(5.5) \\ 9 & 4220(93,1) & 315(6.9) \\ 10 & 4161(95.6) & 190(4.4) \\ 11 & 4630(94.5) & 271(5.5) \\ \text { Ave. } & 4768(94.7) & 265(5.3)\end{array}$

as compared with the untreated azuki bean; in the AK-leaf beans, weight was even greater than the azuki bean.

The scion (azuki)-stock (kidney bean) ratio of leaf areas in the AK-leaf plant is given in Table 3, showing that the scion leaves occupied only less than 10 per cent of the total leaf areas. This suggests that in this graft combination the growth of scion was.

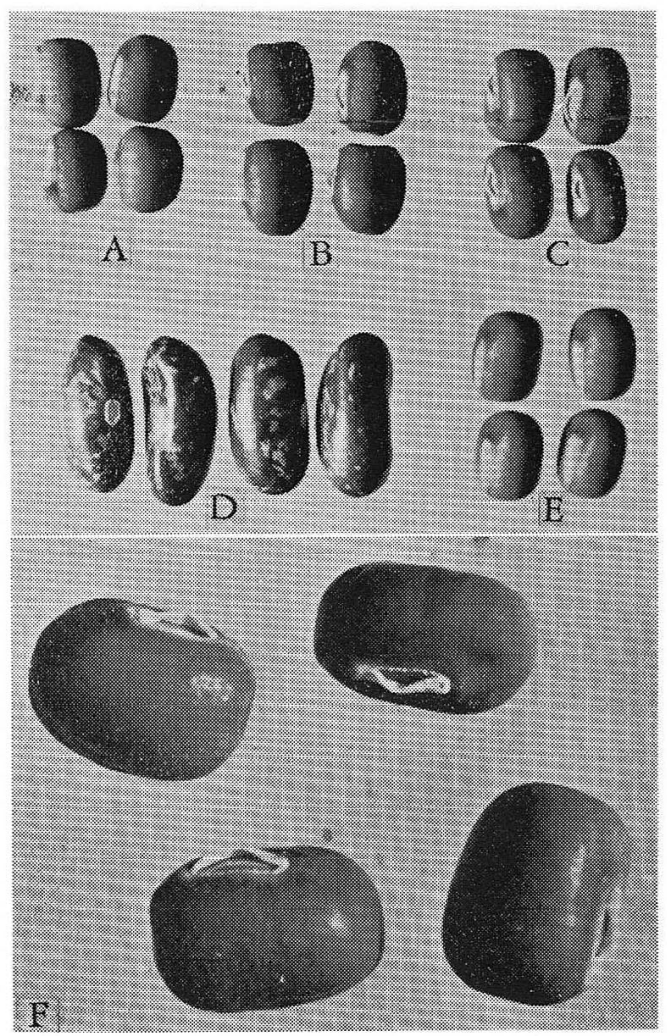

Fig. 4. Beans harvested from the grafted and the control bean plants

A : A-leaf beans. B. AK-leaf beans. C : Kleaf beans. D : control-kidney beans. E : control-azuki beans. F : enlargement of Kleaf beans, showing malformation at navel. 
generally incomplete.

In the $\mathrm{K}$ - and $\mathrm{AK}$-leaf plants, in which the kidney bean leaves were left intact, most beans were deformed of their navels (Fig. 4). Since no deformity occurred in the A-leaf bean, it might have been caused by the presence of leaves of the stock kidney bean.

Development of the azuki bean weevil The results of rearing the azuki bean weevil on beans of the grafted and untreated plants are given in Table 4. The pre-imaginal mortality, which was calculated from the number of eggs hatched and the adults emerged, did not differ significantly between the A-leaf and the control-azuki beans. On the other hand, the mortality was significantly higher on the $\mathrm{K}$ - and AKleaf beans than on the control $(P<0.001)$.
In the AK-leaf plant, there was no correlation between the scion-stock leaf area ratio and the percentage survival on its beans.

After the adult emergence completed, the beans were dissected in order to know the status of insects that failed to develop. It was found that the high mortality on the $\mathrm{K}$ - and AK-leaf beans was due to the early death of newly hatched larvae immediately after they had burrowed through the seedcoat. Despite the variable mortality, the duration of the pre-imaginal development was not significantly different among groups.

Develomfnt of the Mexican bean weevil The results of rearing experiment with beans of the grafted and untreated plants are given in Table 5 . On every group of beans

Table 4. Development of Callosobruchus chinensis

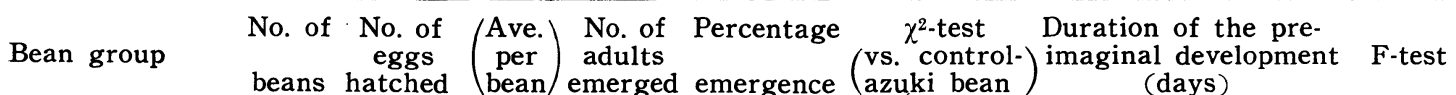
beans hatched (bean) emerged emergence (azuki bean) (days)

\begin{tabular}{|c|c|c|c|c|c|c|c|c|c|c|c|c|}
\hline $\begin{array}{l}\text { A-leaf } \\
\text { bean }\end{array}$ & $\begin{array}{l}\text { No. } \\
\text { Ave. }\end{array}$ & $\begin{array}{l}1 \\
2 \\
3 \\
4 \\
5\end{array}$ & $\begin{array}{l}20 \\
15 \\
15 \\
20 \\
15\end{array}$ & $\begin{array}{l}73 \\
57 \\
34 \\
70 \\
47\end{array}$ & $\begin{array}{l}(3.7) \\
(3.8) \\
(2.3) \\
(3.5) \\
(3.1) \\
(3.3)\end{array}$ & $\begin{array}{l}49 \\
48 \\
23 \\
52 \\
39\end{array}$ & $\begin{array}{l}67.1 \\
84.2 \\
67.7 \\
74.3 \\
83.0 \\
75.3\end{array}$ & $\begin{array}{l}\chi^{2}=0.19 \\
\mathrm{P}>0.5\end{array}$ & $\begin{array}{l}35.3 \\
34.8 \\
35.7 \\
34.7 \\
35.2 \\
35.1\end{array}$ & \pm & $\begin{array}{l}2.2 \\
1.7 \\
2.0 \\
1.9 \\
2.2\end{array}$ & \multirow{4}{*}{$\begin{array}{l}\mathrm{F}=1.19 \\
\mathrm{P}>0.05\end{array}$} \\
\hline $\begin{array}{l}\text { K-leaf } \\
\text { bean }\end{array}$ & $\begin{array}{l}\text { No. } \\
\text { Ave. }\end{array}$ & $\begin{array}{l}1 \\
2 \\
3 \\
4 \\
5 \\
6\end{array}$ & $\begin{array}{l}20 \\
15 \\
15 \\
20 \\
15 \\
15\end{array}$ & $\begin{array}{l}74 \\
70 \\
60 \\
88 \\
43 \\
50\end{array}$ & $\begin{array}{l}(3.7) \\
(4.1) \\
(4.0) \\
(4.4) \\
(2.9) \\
(3.3) \\
(3.7)\end{array}$ & $\begin{array}{l}16 \\
14 \\
29 \\
64 \\
22 \\
34\end{array}$ & $\begin{array}{l}21.6 \\
20.0 \\
48.3 \\
72.7 \\
51.2 \\
68.0 \\
47.0\end{array}$ & $\begin{array}{l}=18.86 \\
<0.001\end{array}$ & $\begin{array}{l}33.6 \\
36.1 \\
34.4 \\
34.3 \\
35.5 \\
35.0 \\
34.8\end{array}$ & \pm & $\begin{array}{l}1.7 \\
2.2 \\
1.8 \\
2.0 \\
2.6 \\
2.0\end{array}$ & \\
\hline $\begin{array}{c}\text { AK-leaf } \\
\text { bean }\end{array}$ & $\begin{array}{l}\text { No. } \\
\begin{array}{r} \\
\\
1 \\
1 \\
\text { Ave. }\end{array}\end{array}$ & $\begin{array}{r}1 \\
2 \\
3 \\
4 \\
5 \\
6 \\
7 \\
8 \\
9 \\
10 \\
11\end{array}$ & $\begin{array}{l}20 \\
15 \\
20 \\
20 \\
20 \\
20 \\
20 \\
15 \\
20 \\
20 \\
15\end{array}$ & $\begin{array}{r}81 \\
49 \\
82 \\
64 \\
63 \\
110 \\
71 \\
39 \\
68 \\
95 \\
66\end{array}$ & $\begin{array}{l}(4.1) \\
(3.3) \\
(4.1) \\
(3.2) \\
(3.2) \\
(5.5) \\
(3.6) \\
(2.6) \\
(3.4) \\
(4.8) \\
(4.4) \\
(3.8)\end{array}$ & $\begin{array}{l}18 \\
27 \\
34 \\
36 \\
49 \\
62 \\
44 \\
15 \\
46 \\
20 \\
50\end{array}$ & $\begin{array}{l}22.2 \\
55.1 \\
41.5 \\
56.3 \\
77.8 \\
56.4 \\
62.0 \\
38.5 \\
67.7 \\
21.2 \\
\mathbf{7 5 . 8} \\
\mathbf{5 2 . 2}\end{array}$ & $\begin{array}{l}=13.90 \\
<0.001\end{array}$ & $\begin{array}{l}34.8 \\
36.1 \\
34.8 \\
34.5 \\
34.4 \\
33.8 \\
34.3 \\
35.0 \\
34.9 \\
33.8 \\
34.5 \\
34.6\end{array}$ & \pm & $\begin{array}{l}1.7 \\
2.0 \\
1.8 \\
1.8 \\
2.0 \\
1.6 \\
1.6 \\
2.3 \\
1.9 \\
1.5 \\
1.4\end{array}$ & \\
\hline $\begin{array}{c}\text { Control } \\
\text { Azuki } \\
\text { bean }\end{array}$ & Ave. & $\begin{array}{l}1 \\
2 \\
3 \\
4 \\
5\end{array}$ & $\begin{array}{l}30 \\
30 \\
30 \\
30 \\
30\end{array}$ & $\begin{array}{r}126 \\
90 \\
126 \\
88 \\
109\end{array}$ & $\begin{array}{l}(4.2) \\
(3.0) \\
(4.2) \\
(2.9) \\
(3.6) \\
(3.6)\end{array}$ & $\begin{array}{r}111 \\
69 \\
96 \\
69 \\
72\end{array}$ & $\begin{array}{l}88.1 \\
76.7 \\
76.2 \\
78.4 \\
66.1 \\
77.1\end{array}$ & - & $\begin{array}{l}34.7 \\
35.1 \\
34.0 \\
33.7 \\
34.5 \\
34.4\end{array}$ & \pm & $\begin{array}{l}2.1 \\
2.1 \\
1.8 \\
1.6 \\
2.0\end{array}$ & \\
\hline
\end{tabular}

Control
bean $\left\{\begin{array}{lllllll}\text { No. } & 4 & 20 & 118 & (5.9) & 0 & 0.0\end{array}\right.$


Table 5. Development of Zabrotes subfasciatus

\begin{tabular}{|c|c|c|c|c|c|c|c|c|c|c|}
\hline \multicolumn{2}{|c|}{ Bean group } & \multirow{2}{*}{$\begin{array}{c}\begin{array}{c}\text { No. of } \\
\text { beans }\end{array} \\
15 \\
15 \\
10\end{array}$} & \multirow{2}{*}{$\begin{array}{c}\begin{array}{c}\text { No. of } \\
\text { eggs } \\
\text { hatched }\end{array} \\
205 \\
108 \\
98\end{array}$} & \multirow{2}{*}{ 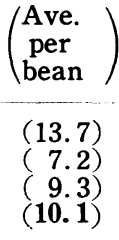 } & \multirow{2}{*}{$\begin{array}{c}\begin{array}{c}\text { No. of } \\
\text { adults } \\
\text { emerged }\end{array} \\
87 \\
54 \\
62\end{array}$} & \multirow{2}{*}{$\begin{array}{c}\text { Percentage } \\
\text { emergence } \\
42.4 \\
50.0 \\
66.7 \\
53.0\end{array}$} & \multicolumn{3}{|c|}{$\begin{array}{l}\text { Duration of the pre- } \\
\text { imaginal development } \\
\text { (days) }\end{array}$} & \multirow{2}{*}{ F-test } \\
\hline $\begin{array}{c}\text { A-leaf } \\
\text { bean }\end{array}$ & $\begin{array}{r}\text { No. } 6 \\
7 \\
8 \\
\text { Ave. }\end{array}$ & & & & & & $\begin{array}{l}41.7 \\
44.6 \\
41.4 \\
42.6\end{array}$ & & $\begin{array}{l}3.4 \\
3.3 \\
3.1\end{array}$ & \\
\hline $\begin{array}{c}\text { K-leaf } \\
\text { bean }\end{array}$ & $\begin{array}{ll}\text { No. } 1 \\
\\
\text { Ave. }\end{array}$ & $\begin{array}{l}10 \\
10\end{array}$ & $\begin{array}{l}110 \\
130\end{array}$ & $\begin{array}{l}(11.0) \\
(13.0) \\
(12.0)\end{array}$ & $\begin{array}{l}46 \\
98\end{array}$ & $\begin{array}{l}41.8 \\
75.4 \\
58.6\end{array}$ & $\begin{array}{l}38.6 \\
37.6 \\
38.1\end{array}$ & \pm & $\begin{array}{l}2.1 \\
1.7\end{array}$ & \\
\hline $\begin{array}{c}\text { AK-leaf } \\
\text { bean }\end{array}$ & $\begin{array}{rr}\text { No. } & 3 \\
4 \\
5 \\
6 \\
\\
7\end{array}$ & $\begin{array}{l}20 \\
20 \\
20 \\
20 \\
20\end{array}$ & $\begin{array}{l}268 \\
186 \\
184 \\
150 \\
236\end{array}$ & $\begin{array}{r}(13.4) \\
(9.3) \\
(9.2) \\
(7.5) \\
(11.8) \\
(10.2)\end{array}$ & $\begin{array}{r}134 \\
115 \\
95 \\
93 \\
147\end{array}$ & $\begin{array}{l}50.0 \\
61.8 \\
51.6 \\
62.0 \\
62.3 \\
57.5\end{array}$ & $\begin{array}{l}38.0 \\
38.1 \\
39.9 \\
37.8 \\
39.1 \\
\mathbf{3 8 . 6}\end{array}$ & \pm & $\begin{array}{l}2.2 \\
2.0 \\
2.6 \\
2.1 \\
3.2\end{array}$ & $\begin{array}{l}\mathbf{F}=31.32 \\
P<0.01\end{array}$ \\
\hline $\begin{array}{l}\text { Control } \\
\text { Azuki } \\
\text { bean }\end{array}$ & $\begin{array}{l}\text { No. } 2 \\
12 \\
13 \\
\text { Ave. }\end{array}$ & $\begin{array}{l}20 \\
20 \\
20\end{array}$ & $\begin{array}{l}197 \\
246 \\
256\end{array}$ & $\begin{array}{l}(9.9) \\
(12.3) \\
(12.8) \\
(11.7)\end{array}$ & $\begin{array}{r}94 \\
124 \\
89\end{array}$ & $\begin{array}{l}47.7 \\
50.4 \\
34.8 \\
44.3\end{array}$ & $\begin{array}{l}46.7 \\
47.2 \\
44.5 \\
46.1\end{array}$ & \pm & $\begin{array}{l}3.1 \\
3.1 \\
3.5\end{array}$ & \\
\hline $\begin{array}{l}\text { Control } \\
\text { Kidney } \\
\text { bean }\end{array}$ & $\begin{array}{l}\text { No. } \begin{array}{r}1 \\
2 \\
3\end{array} \\
\text { Ave. }\end{array}$ & $\begin{array}{l}10 \\
10 \\
10\end{array}$ & $\begin{array}{l}168 \\
143 \\
207\end{array}$ & $\begin{array}{l}(16.8) \\
(14.3) \\
(20.7) \\
(17.3)\end{array}$ & $\begin{array}{l}144 \\
132 \\
125\end{array}$ & $\begin{array}{l}85.7 \\
92.3 \\
60.4 \\
79.5\end{array}$ & $\begin{array}{l}36.9 \\
37.9 \\
37.7 \\
\mathbf{3 7 . 3}\end{array}$ & \pm & $\begin{array}{l}1.4 \\
1.1 \\
1.3\end{array}$ & \\
\hline
\end{tabular}

the percentage adult emergence was considerably low ; this was partly due to the crowded condition of rearing, which had been caused by an erroneous procedure, allowing about 10 eggs to hatch on each bean.

The percentage emergence was the highest on the control-kidney beans, and the lowest on the control-azuki beans. Since the kidney bean is about 2.5 times as large as the azuki bean in size, the remarkable difference in mortality between insects on the azuki and kidney beans could not be ascribed to the qualitative difference in chemical composition of respective beans, but owing to quantitative difference of food available, or density effect caused by different bean size. In another experiment in which the population density was controlled more uniformly, these was no substantial difference in the percentage survival between the azuki and kidney beans. The weevils on beans of three operated groups gave intermediate mortality.

A significant feature of the results was the difference in the duration of larval development. On the azuki beans, the weevil took about 9 days longer than on the kidney beans for its development. The results of

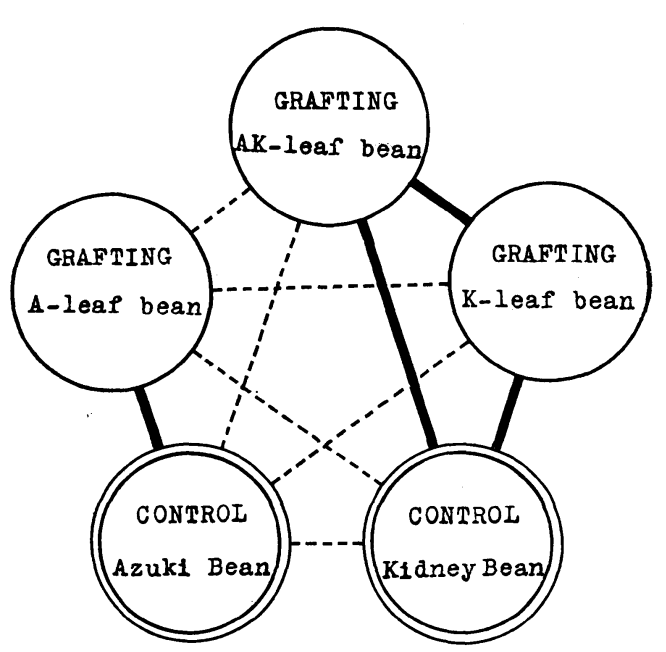

Fig. 5. Comparison of the duration of pre-imaginal development of Zabrotes subfasciatus on grafted and normal beans

...... : significance at $1 \%$ level

_ : no significant difference

statistical tests among different bean rearings are illustrated in Fig. 5. There was no significant difference in the developmental period among the weevils on the $\mathrm{K}$ - and AK-leaf beans and the control-kidney bean. 
It should be noticed that in all these groups the leaves of the kidney bean were responsible for producing the beans. The developmental period of the weevil on these three groups of beans is significantly different from that on the A-leaf bean or the controlazuki bean, and the latter two were closely similar each other in their effect on the development of larvae.

\section{DISCUSSION}

The beans of the $\mathrm{K}$ - and AK-leaf plants caused a high mortality in the azuki bean weevil during the early stage of larval development. This suggests strongly the transmission of the growth-inhibiting substances of the kidney bean to the scion azuki beans. If this assumption is correct, it follows that the leaves of the kidney bean plant play an important role in the synthesis of these critical substances. In the AK-leaf plant, there was no correlation between the scion-stock leaf areas ratio and the percentage emergence of the azuki bean weevil. This was presumably due to the small percentage of the scion azuki bean leaves, which probably took little part in bean production as compared with the stock leaves.

Despite the high larval mortality, the duration required for development of the azuki bean weevil on beans of the grafted plants is approximately equal to that on the azuki beans. Therefore, the substances in question do not inhibit the entire course of the larval development, but they exert their effects only at the early stage of larval life, particularly soon after hatching.

Though there was a high initial mortality, a number of the azuki bean weevils could complete their development on the K-leaf bean which had been formed through the metabolic activity of the kidney bean leaves and roots. This might partly be ascribed to the selective intake of the kidney bean substances by the azuki scion or the scion beans, and partly to the synthesis of the azuki bean substances by the scion stalks and pods. Further investigations are required to ascertain this point.
The Mexican bean weevil developed as rapidly on the $\mathrm{K}$ - and $\mathrm{AK}$-leaf beans as on the control-kidney beans. On the contrary, the development delayed on the A-leaf beans and on the control-azuki beans. There might be two possible explanations for this fact :

1. The kidney beans and azuki beans supported nutritionally by the kidney bean plant are more favourable nutritionally for the development of larvae than the normal azuki beans.

2. Certain substance(s) having adverse activity for the larval development are present in the azuki bean. The results obtained with the rearing experiment on the A-leaf beans suggest that the azuki leaves are responsible for the production of such substances.

These two hypotheses are mutually unexclusive, and in every case it is likely that the roots of the bean plants are of little significance concerning the synthesis of such growth-promoting or growth-retarding substances. As to the larval growth of the Mexican bean weevil, the chemical characteristics of the $\mathrm{K}$ - and AK-leaf beans are more intimate with the kidney beans than the azuki beans, but the A-leaf beans resemble to the normal azuki beans.

The leaves of the bean plants are more important than the roots in determining the chemical characteristics of the beans relevant to the nutritional physiology of the bean weevils.

\section{SUMMARY}

The azuki bean weevil (Callosobruchus chinensis L.), develops well when fed on the azuki beans but not on the kidney beans, which contain unknown substances inhibiting its early development. On the other hand, the Mexican bean weevil (Zabrotes subfasciatus BоH.), is able to develop on the kidney beans as well as on the azuki beans, the larvae developing more rapidly on the former beans. In order to determine the plant part that is responsible for synthesis of the critical substances, grafting was introduced and the resulting seeds were 
submitted for feeding to the weevils. The kidney bean plant was used as a stock and the azuki plant as a scion, and the leaves of the scion or stock were removed as follows :

A-leaf treatment--the leaves of the kidney bean stocks were removed.

K-leaf treatmet --the leaves of the azuki scions were removed.

AK-leaf treatment - - all leaves were left intact.

When the two species of the bean weevils were fed on the beans harvested from these grafted plants, it was found that the A-leaf beans were similar to the normal azuki beans in their effect on the development of two species of weevils. On the other hand, the beans of the $\mathrm{K}$ - and AK-leaf plants resulted in the decreased percentage of adult emergence of the azuki bean weevil, but in the increasing growth rate of the Mexican bean weevil. Such effects are essentially similar to those of the normal kidney beans.

From these findings, it is concluded that the substance in the kidney beans, which inhibits development of the azuki bean weevil, is derived mainly from the metabolic activity of the kidney bean leaves, and that the different chemical composition of the two species of beans which cause the different growth rate of the Mexican bean weevil is also ascribed to the function of leaves. The root system seems to be of little importance for the synthesis of these critical substances.

\section{REFERENCES}

Bunr, H. (1954) Der Zuchter $24: 185 \sim 193$.

siir, S. (1952) Bull. Nat. Inst. Agric. Sci. C-4 : $185 \sim 256$.

-Müller, H. J. and E. Hennig (1960) Ent. exp. \& appl. $3: 157 \sim 170$.

Umeya, K. and E. Imai (1963) Japanese J. Appl. Ent. Zool. $7: 154 \sim 156$.

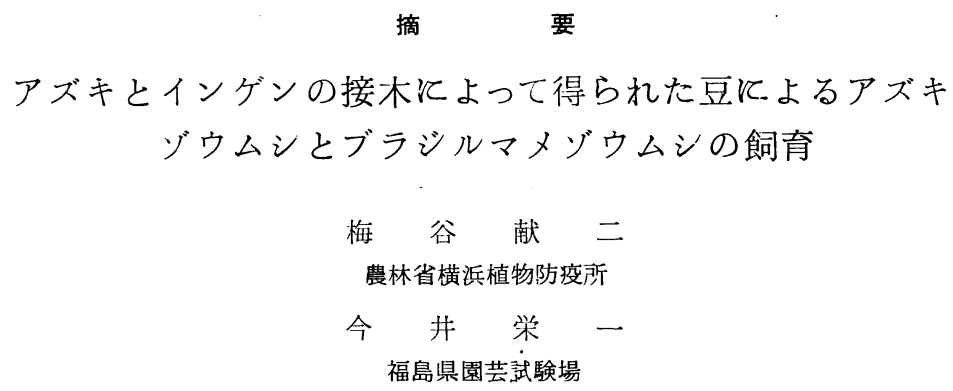

アズキゾウムシ Callosobruchus chinensis はアズキで はよく育つが，インゲンでは未知の生育阻害物質が含ま れているために生育することができず，1 令幼虫で全部 死亡する。またブラジルマメゾウムシ Zabrotes subfasciatus はアズキでもインゲンであよく育つが, 生育速度 はインゲンでより速い。筆者らはこれらの原因となる物 質が植物体のどの部分で生成されるかを知る目的で接林 による試験をおこなった。

インゲンを砧, アズキを穂としてそれぞれ幼苗の時期 に接木し，その後つぎのような管理をおこなって穂木の アズキを収穫した。

アズキ葉区一一接木豆（穂林に結実したアズキ）の成
分の生成にアズキ葉とインゲンの根だけを関与させ るためにインゲンの葉芽を全部除去する。 インゲン葉区——同様にインゲンの葉, 根だけを関与 させるためにアズキの葉芽を全部除去する。 両葉区一一同様にアズキの葉およびインゲンの葉, 根 を関与させるために砧・穂木ともに葉芽を残して放 置する。

これらの処理によって得られたアズキを前記 2 種のマ メゾウムシに与えた結果, アズキ葉区は両種とも無処理 のアズキで飼育した場合と変わりがなかったが，インゲ ンの葉が関与したインゲン葉区と両葉区においては，ア ズキゾウムシで羽化率の低下が劷められ，またブラジル 
マメゾウムシも，インゲンで飼育した場合と同様な生育 期間の短縮が認められた。

以上の結果からインゲンに含まれるアズキゾウムシの 生育阻害物質の生成にインゲンの葉が重要な関係を持っ ているとと，および，ブラジルマメゾウムシの生育期間 に差をむたらす原因となるアズキまたはインゲンに含ま
れる末知の物質の生成にインゲン葉またはアズキ葉が関 与し，根の影響は少ないと推定するにいたった。

なお，各接木豆は形態的に無処理のアズキと同様であ ったが，インゲン葉の関与したインゲン葉区上両葉区の 豆だけヘソ部に奇形を生じた。

時 報

日米「昆虫生化学」共同セミナー

昭和 40 年 7 月 28 日より 8 月 3 日まで千葉大学医学部で 開催次

の講演があった。 8 月 2 日までは定員制で正式参加者24名。 8 月

3 日は公開され約70人の参加者があった。

LEVENBooK, L.： Free amino acids and ninhidrin positive substances during metamorphosis of the blow fly Phormia regina.

MiURA. Y.: Nucleic acids metabolism of posterior. silk glands.

MARUYAMA, K. : A study on contractile proteins of insect muscle

MukaI, J. and S. AKune: A nuclease from Bombyx mori.

Clyton. R. B. : Utilization of sterols in insects and its relation to cell membrane structure.

IsHII, S. and S. KAWAHARA : Utilization of sterols in cloth moths.

IKekAwA, N. and M. SAIto-Suzuki : Sterols in silkworms.

Chefurka, W. : Catabolic fate of glucose in insects.

Wyatт, G. R. : Enzymes and regulation of carbohydrate interconversion in insects.

Hirano. C. and S. Tojo: Uric acid pattern in insects in relation to their metamorphorsis.

UMEBACHI. Y.: Yellow pigment of papilionid butterfly.

Tsujita, M. : Studies on specific chromoproteins purified from chromogranules in hypodermal cells of silkworm larvà.

Ogita, Z. : Genetico-biochemical studies on the isozymes in Musca domestica.

Hodgson. E. : Nature of biosynthesis of phospholipids in insects.
Chino, H. : Fat release and transport in insects.

Stevenson, E.: Insect flight muscle metabolism.

Corrigan, J. J. : Stereospecific aspects of amino acid metabolism in insects.

Shigematsu, H. : Aspect for fibroin synthesis and nucleic acid metabolism.

ShimURA. K. : Biosynthesis of silk fibroin in a cellfree system.

SHIMURA. K. : Fibroin sythesis.

Wyatt. G.R. : Biochemistry of hormonal actions during insect metamorphosis.

CoRrigan, J. J. : Comparison of protein synthesis in insects with that in vertebrates.

ChEFURKA, W.: The role of mitochondria in insect biochemistry.

\section{第29回昆虫生理談話会}

4 月 1 日午後 2 時より農技研新館会議室において次の話があ った。参加者約 60 名

昆虫蛋白の電気泳動飞よる分離
吉武 成美 (東 大 農)

免度化学の昆虫学への利用

西島浩（帯広音大）

\section{第30回昆虫生理談話会}

7 月 9 日午後 1 時 30 分より大手町農協会館 8 階第 2 会議室飞打 いて次の話があった。参加者70名。

Free amino acid during insect development.

Dr. L. LevenbooK (National Institutes of Health, U. S. A.)

Trehalose and its metabolism in insects. Prof. G. R. Wyatt (Yale University) 